\title{
Fatal case of imported human rabies in Amadora, Portugal, August 2011
}

A Santos ${ }^{1}$, E Calé2 ${ }^{2}$ L Dacheux³ , H Bourhy³, J Gouveia4, P Vasconcelos (pvasconelos@dgs.pt)

1. Public Health Department of Amadora, Portugal

2. Directorate-General of Health, Lisbon, Portugal

3. WHO Collaborating Centre for Reference and Research on Rabies, Institut Pasteur, Paris, France

4. Hospital Pulido Valente, Centro Hospitalar Lisboa Norte, Lisbon, Portugal

We report on a case of imported human rabies in Portugal, in July 2011 in a woman who presented initially complaining of back pain, without relating exposure to animal bites. She had travelled from Portugal to Bissau, Guinea-Bissau, in April where she had been bitten by a dog on 1 May. She was diagnosed with rabies on 26 July and died two weeks later in spite of being treated following the Milwaukee protocol.

\section{Case report}

On 19 July 2011, a 41-year-old woman, born in GuineaBissau and a resident of Amadora, Portugal, consulted the emergency department of the local hospital with lower back pain radiating to the left leg. She did not relate having been exposed to animal bites and was not asked about animal exposure or travel history. She was discharged with symptomatic therapy. As the hypothesis of rabies was not initially suspected she was not vaccinated. Five days later, on 24 July, she returned to the emergency department presenting new symptoms: anorexia, hydrophobia, aggressiveness and agitation. She was neurologically evaluated and diagnosed with an encephalitic syndrome and peripheral polyneuropathy, with the working diagnosis of rabies encephalitis. The same day, she was transferred to the intensive care unit (ICU) of the hospital Pulido Valente, Lisbon.

On 25 July, biological samples were taken (a skin biopsy, a cerebrospinal fluid (CSF) sample and three saliva samples) and sent to the World Health Organization (WHO) Collaborating Centre for Reference and Research on Rabies, Institut Pasteur, France, for diagnosis. Based on clinical symptoms, treatment following the Milwaukee protocol was initiated [1]. This protocol was applied for the first time in 2004, when a teenager survived clinical rabies caused by the bite of a bat, following supportive intensive care and the use of an anti-excitatory strategy that included general anaesthesia, antiviral drugs and neuroprotection, with amantadine, ketamine, midazolam and ribavirin [1]. An amended version of the protocol (V3.1) [2] was used to treat the patient described (amantadine, ketamine, midazolam, nimodipine and valproic acid).

One day later, on 26 July, the rabies diagnosis was confirmed by reverse transcription polymerase chain reaction, RT-PCR, [3] on the three saliva samples. The CSF and the skin biopsy remained negative. On 29 July, the typing results indicated that the causal virus was a lyssavirus of the rabies virus species belonging to lineage Africa 2 group B, which usually circulates in Senegal, Guinea-Bissau and Sierra Leone [4]. Despite treatment with an adapted version of the updated Milwaukee protocol including invasive mechanical ventilation and heavy sedation, the patient's condition progressively worsened and finally died 15 days after diagnosis.

Case history obtained through relatives, revealed that the patient had travelled to Bissau, capital of GuineaBissau on 22 April. In Bissau on 1 May, she was bitten by a dog in the lower left limb and the dog was shot on the same day, a common measure in a country where animal rabies is enzootic. No tests were carried out on the dog to confirm rabies. The patient went to the local health authorities of Bissau to report having been bitten by a dog and as vaccine was not available in the country she was not vaccinated. She returned to Portugal on 28 May without any symptoms and had not initiated any vaccination schedule. While in Portugal, she developed the first symptoms.

\section{Public health measures}

On 26 July, the local public health department in Amadora received information of the suspicion of a case of human rabies from the Hospital Pulido Valente in Lisbon. The health authority in Amadora notified the Directorate-General of Health in Lisbon and on the same day, interviewed the patient's family. It was possible to identify her contacts among relatives and health professionals. Risk assessments were carried out for those who might have been in contact with the case. Human infection usually occurs following 
a transdermal bite or scratch by an infected animal. Transmission may also occur when infectious material, usually saliva, comes into direct contact with the victim's mucosa or with fresh skin wounds.

Six individuals were identified for treatment with postexposure prophylaxis (PEP) which consisted of four intramuscular doses of rabies vaccine, $1 \mathrm{ml}$, with two doses on day o, followed by one dose each on day seven and 21. Although scientific evidence for human-tohuman transmission is limited to few cases worldwide $[5,6]$, it was decided to also give PEP to the husband, considering the sexual intercourse during the communicability period. Furthermore, five health professionals from the Lisbon central hospital, who performed or helped with invasive procedures, were vaccinated following specific indications from the DirectorateGeneral of Health. Fast identification of all the persons who had been in contact with the patient was done through efficient cooperation between the hospitals, local public health authorities and the DirectorateGeneral of Health. All parties communicated with each other and supported the epidemiological investigation in a coordinated way in order to allow for rapid application of public health measures. The case was reported through the European Union Early Warning and Response System (EWRS) and the focal point of the World Health Organization International Health Regulations (IHR) in Guinea-Bissau was contacted.

New guidelines for epidemiological inquiries as well as for vaccination and prophylaxis were developed by the Portuguese Directorate-General of Health following the event.

\section{Epidemiological background}

Rabies is a viral zoonosis largely distributed worldwide. The natural reservoirs are mainly dogs (canine rabies represents $99 \%$ of the source of infection for humans [7]), foxes, raccoon dogs, skunks and bats. However, a large number of other mammals can be infected and can act as vectors. In Europe, the main epidemiologic cycle of rabies in sylvatic terrestrial non-flying animals is maintained by the red fox (Vulpes vulpes) and the raccoon dog (Nyctereutes procyonoides). Large vaccination campaigns of foxes were implemented in numerous western and central European countries. However, fox rabies is still present in the eastern and in some southern parts of Europe, such as Croatia, Serbia and Slovenia $[8,9]$. Bat rabies has also been diagnosed in numerous European countries, with reports of transmission to humans. There have been three confirmed deaths since 1985 [10]. Spill-over infections from bat rabies to terrestrial mammals [10] is still a threat, thereby maintaining its potential to infect humans.

The main risk of canine rabies resides in the translocation of unvaccinated animals originating from countries bordering the east and south of Europe [11,12]. From 2008 to 2011, at least three reports have described the importation of rabid dogs from Africa to Europe [13-15].
One of the reports concerned an infected dog imported from Morocco, identified in France, that travelled to Portugal and Spain and which may have infected susceptible dogs [14]. Between January 2000 and January 2009, there were 13 reports of cases of imported human rabies in Europe [9]. The 2010 European Centre for Disease Prevention and Control (ECDC) annual epidemiological report describes one case of human rabies in the European Union (EU), a woman in a rural area of Romania that had been bitten by a fox [16]. The annual average number of cases of human rabies in the EU has been limited to one in the last years. This single case would seem to confirm that trend [16].

\section{Conclusion}

Rabies is a zoonotic disease fatal in humans which can be prevented either through vaccination or if adequate measures are applied after exposure [17] Portugal is a country free of rabies since 1960 [18] and the probability of an autochthonous case is virtually inexistent. However, the possibility of imported cases, especially from the Portuguese-speaking African countries (mainly Angola and Guinea-Bissau where rabies is an epizootic) exists, mainly because of the influx of migrants to Portugal and to other parts of Europe [11,12]. This report, and a recent report about an imported rabid puppy [19], confirms the need for vigilance with regard to human and animal rabies.

The handling of the case described is an example of efficient coordination between the local public health authorities, the hospital, the Portuguese DirectorateGeneral of Health and the collaboration with an international laboratory, the Institut Pasteur in Paris. There was constant and rapid exchange of information between these entities to confirm the case and to identify the exposed individuals. The case is another example of the failure of the Milwaukee protocol applied to rabid patients $[20,21]$.

\section{References}

1. Willoughby RE Jr, Tieves KS, Hoffman GM, Ghanayem NS, Amlie-Lefond CM, Schwabe MJ, et al. Survival after treatment of rabies with induction of coma. N Engl J Med. 2005; 352(24):2508-14.

2. The Medical College of Wisconsin. Care of rabies version 3.1 Last updated June 22, 2009. Available from: http://www. mcw.edu/FileLibrary/Groups/Pediatrics/InfectiousDiseases/ Milwaukee_rabies_protocol_V3_1.pdf

3. Dacheux L, Reynes IM, Buchy P, Sivuth O, Diop BM, Rousset D, et al. A reliable diagnosis of human rabies on analysis of skin biopsy specimens. Clin Infect Dis. 2008;47(11):1410-7.

4. Talbi C, Holmes EC, de Benedictis P, Faye O, Nakouné E, Gamatié D, et al. Evolutionary history and dynamics of dog rabies virus in western and central Africal. J Gen Virol. 2009;90(Pt 4):783-91.

5. Houff SA, Burton RC, Wilson RW, Henson TE, London WT, Baer GM et al. Human-to-human transmission of rabies virus by corneal transplant. N Engl J Med. 1979;300(11):603-4

6. World Health Organization. Two rabies cases following corneal transplantation. Wkly Epidemiol Rec. 1994;69:330.

7. Knobel DL Cleaveland S, Coleman PG, Fèvre EM, Meltzer MI, Miranda ME et al. Re-evaluating burden of rabies in Africa and Asia. Bull World Health Organ. 2005;83:360-8.

8. De Benedictis P, Gallo T, Iob A, Coassin R, Squecco G, Ferri $\mathrm{G}$, et al. Emergence of fox rabies in north-eastern Italy. Euro 
Surveill. 2008;13(45):pii=19033. Available from: http://www. eurosurveillance.org/ViewArticle.aspx?Articleld=19033

9. De Benedictis P, Capua I, Mutinelli F, Wernig JM, Arič T, Hostnik P. Update on fox rabies in Italy and Slovenia. Rabies Bulletin Europe. 2009;33(1): 5-7.

10. Dacheux L, Larrous F, Mailles A, Boisseleau D, Delmas O, Biron C, et al. European bat Lyssavirus transmission among cats, Europe. Emerg Infect Dis. 2009;15(2):280-4.

11. Bourhy H, Dacheux L, Strady C, Mailles A. Rabies in Europe in 2005. Euro Surveill. 2005;10 (11): 213-6. Available from: http:// www.eurosurveillance.org/ViewArticle.aspx?Articleld $=575$

12. Gautret $P$, Ribadeau-Dumas F, Parola $P$, Brouqui $P$, Bourhy $H$. Risk for rabies importation from north Africa. Emerg Infect Dis. 2011;17(12):2187-93.

13. French multidisciplinary investigation team. Rapid communication: Identification of a rabid dog in France illegally introduced from Morocco. Euro Surveill. 2008;13(11) Available from: http://www.eurosurveillance.org/ViewArticle. aspx?Articleld $=8066$.

14. A Mailles, D Boisseleau, L Dacheux, C Michalewiscz, C Gloaguen, N Ponçon et al. Rabid dog Illegally Imported to France from Morrocco, August 2011. Euro Surveillance. 2011;16(33) Available from: http://www.eurosurveillance.org/ ViewArticle.aspx?Articleld $=19946$.

15. The French* and Belgian** multidisciplinary investigation teams. Identification of a rabid dog illegally introduced from the Republic of the Gambia to Belgium and France. Euro Surveill. 2008;13(18):pii=18856. Available from: http://www. eurosurveillance.org/ViewArticle.aspx?Articleld=18856

16. European Centre of Disease Prevention and Control. Annual Epidemiological Report on Communicable Diseases in Europe 2011- Reporting on 2009 survaillance data and 2010 epidemic intelligence data. Stockholm: ECDC; 2011; 174-175. Available from: http://ecdc.europa.eu/en/publications/ Publications/1111_SUR_Annual_Epidemiological_Report_on Communicable_Diseases_in_Europe.pdf.

17. World Health Organization. Wkly Epidemiol Rec. 2010;85(32): 309-20. Available from: http://www.who.int/wer/2010/ wer8532.pdf

18. Portugal. Ministério das Finanças e do Plano,Ministério da Administração Interna. Ministério da Agricultura e Pescas, Ministério da Educação e Ciência, Ministério da Agricultura. Decreto nํ 8/79 de 27 de Janeiro. Diário da República. 1979 Jan ; Serie I (23): 112. Portuguese. Available from: http://dre.pt/ pdfgratis/1979/01/02300.pdf

19. van Rijckevorsel GG, Swaan CM, van den Bergh JP, Goorhuis A, Baayen D, Isken L, Timen A, van den Hoek A. Rabid puppy-dog imported into the Netherlands from Morocco via Spain, February 2012. Euro Surveill. 2012;17(10):pii=20112. Available online: http://www.eurosurveillance.org/ViewArticle. aspx?Articleld $=20112$

20. McDermid RC, Saxinger L, Lee B, Johnstone J, Gibney RT, Johnson M, Bagshaw SM. et al. Human rabies encephalitis following bat exposure: failure of therapeutic coma. CMAJ. 2008;178(5):557-61.

21. Jackson AC. Rabies in the critical care unit: diagnostic and therapeutic approaches. Can J Neurol Sci. 2011;38(5):689-95. 